\title{
Analisis Pengaruh Faktor Fundamental terhadap Harga Saham pada Perusahaan yang Konsisten Terdaftar di Jakarta Islamic Index
}

Analysis of the influence of fundamental factors on stock prices in companies that are consistently listed on the Jakarta Islamic Index

\section{Fadhillah Syahba Adrisa}

Program Studi D4 Keuangan Syariah, Politeknik Negeri Bandung

E-mail: fadhillah.syahba.ksy16@polban.ac.id

\section{Ade Ali Nurdin}

Jurusan Akuntansi, Politeknik Negeri Bandung

E-mail: ade.nurdin@polban.ac.id

\section{Iwan Setiawan}

Jurusan Akuntansi, Politeknik Negeri Bandung

E-mail: iwan.setiawan@polban.ac.id

\begin{abstract}
This study aims to determine the effect of fundamental factors on the stock prices of companies that are consistently listed on the Jakarta Islamic Index (JII) during the 2014-2018 period, either partially or simultaneously. Fundamental factors consist of financial ratios, namely Current Ratio (CR), Debt to Equity Ratio (DER), Earning Per Share (EPS), and Return On Equity (ROE), as well as macroeconomic variables represented by Inflation and Bank Indonesia Interest Rates ( $B I$ Rate). The results showed that partially the $\mathrm{ROE}$ variable had a significant effect on JII's stock price, while CR, DER, EPS, Inflation, and BI Rate had a negative and insignificant effect on JII's stock price. Simultaneously the variables CR, DER, EPS, ROE, Inflation, and BI Rate have a significant effect on JII's stock price.
\end{abstract}

Keywords: fundamental factors, stock prices, Jakarta Islamic Index.

\section{Pendahuluan}

Eksistensi pasar modal di Indonesia merupakan salah satu faktor terpenting dalam membangun perekonomian nasional, terbukti telah banyak industri dan perusahaan yang menggunakan pasar modal sebagai sarana untuk berinvestasi dan memperkuat posisi keuangannya. Namun, banyak hal-hal mudharat yang terjadi pada transaksi keuangan di pasar modal konvensional. Diantaranya ialah masih banyaknya unsur-unsur gharar atau ketidakjelasan transaksi yang dilakukan serta terdapat unsur spekulasi dan perjudian. Oleh karena itu, pemerintah mengantisipasi hal tersebut dengan menciptakan dan mengembangkan pasar modal syariah. Besarnya potensi pasar modal syariah dapat dilihat pada peringkat industri keuangan syariah Indonesia yang menempati peringkat ke enam setelah Malaysia, Iran, Saudi Arabia, United Arab Emirates, dan Kuwait pada 2018. (Setiawan dkk., 2020)

Pasar modal syariah dapat idiartikan sebagai kegiatan dalam pasar modal sebagaimana yang diatur dalam Undang-undang pasar modal yang tidak bertentangan dengan prinsip-prinsip syariah. Secara umum kegiatan pasar modal syariah tidak memiliki perbedaan dengan pasar 
modal konvensional, namun terdapat karakteristik dan ketentuan-ketentuan khusus yang mengharuskan produk dan mekanisme transaksi keuangan yang terjadi di pasar modal syariah tidak bertentangan dengan syariat slam.

Pasar imodal syariah dikembangkan dalam rangka memfasilitasi sekaligus mengakomodir kebutuhan umat slam di Indonesia yang ngin melakukan nvestasi berbasis syariah pada produkproduk pasar modal tu sendiri. Dengan beragamnya sarana dan produk nvestasi di ndonesia, masyarakat ndonesia diharapkan akan mampu memiliki alternatif berinvestasi yang disesuaikan dengan keinginan dan kebutuhannya.

Investasi syariah dapat diartikan penempatan suatu dana yang kita miliki saat ni dengan harapan akan memberikan keuntungan dimasa yang akan datang dengan ketentuan-ketentuan yang tidak dilarang dalam prinsip syariah (Aprilia dkk., 2021). Ketika kita telah memutuskan melakukan nvestasi syariah setidaknya kita telah merencanakan untuk memiliki kehidupan yang lebih baik untuk kedepannya. Sebelum melakukan nvestasi syariah, sebaiknya nvestor terlebih dahulu mengetahui beberapa nformasi yang dibutuhkan seperti nformasi mengenai harga saham. Hal ni penting karena ketika nvestor tidak mengetahui nformasi apapun mengenai nvestasi terutama saham, maka bisa saja nvestor mengalami kerugian. Apalagi saham memang memiliki risiko besar sehingga perlu banyak nformasi akurat untuk diketahui.

Banyak sekali faktor yang harus diperhatikan terutama ketika berhubungan dengan harga saham (Awala, dkk., 2020). Harga saham memiliki sifat yang sensitive dan selalu berubah-ubah bahkan setiap detiknya. Nominal harga saham tersebut secara fundamental dapat dipengaruhi oleh kinerja perusahaan serta kondisi makroekonomi. Kinerja perusahaan merupakan kondisi internal yang dapat mempengaruhi nominal harga saham karena semakin baik kinerja perusahaan maka semakin besar pengaruhnya terhadap kenaikan harga saham. Untuk dapat menilai kinerja perusahaan dengan benar dan akurat maka diperlukan analisis laporan keuangan. Alat yang dapat digunakan untuk menganalisis laporan keuangan yaitu dengan rasio keuangan yang menggambarkan kekuatan manajemen dalam mengelola perusahaan. Selain tu, terdapat pula faktor-faktor dari makroekonomi yang dapat mempengaruhi harga saham perusahaan. Faktorfaktor tersebut dapat diartikan juga sebagai faktor fundamental perusahaan. Faktor fundamental juga menitik beratkan pada data-data kunci dalam laporan keuangan untuk memperhitungkan apakah harga saham sudah terapresiasi secara akurat.

Menurut Sudiyatno (2010) untuk dapat mencegah dan mengantisipasi perubahan harga saham yang tidak dapat diperkirakan, maka para nvestor harus melakukan analisis fundamental. Rasio keuangan dan kondisi makroekonomi merupakan ndikator yang tepat untuk dijadikan sebagai alat analisis fundamental. Rasio keuangan yang digunakan berdasarkan financial highlights yaitu khtisar data keuangan penting perusahaan dalam sebuah laporan tahunan meliputi Current Ratio (rasio likuiditas), Return on Equity (rasio profitabilitas), Debt to Equity Ratio (rasio leverage), Earning Per Share (rasio nilai pasar), dan makroekonomi meliputi nflasi dan tingkat suku bunga BI.

\section{Kajian Pustaka}

Analisis Fundamental memiliki hubungan erat kaitannya dengan suatu kegiatan perusahaan termasuk efisiensi dan efektifitas perusahaan tu untuk mencapai tujuan perusahaan tersebut. Secara umum faktor fundamental yang diteliti dalam memprediksi harga saham di masa yang akan datang dengan menggunakan rasio keuangan. Tujuan analisis fundamental untuk menentukan apakah nilai saham berada pada posisi underpriced atau overpriced.

Menurut prinsip fundamental, harga saham suatu perusahaan dapat dipengaruhi oleh kinerja perusahaan serta kondisi makroekonomi. Pendekatan fundamental pada umumnya menitikberatkan pada analisis-analisis untuk mengetahui kondisi fundamental perusahaan yang 
dipengaruhi oleh kondisi perekonomian dan pada khususnya oleh rasio keuangan yang dapat mencerminkan kondisi keuangan serta kinerja suatu perusahaan dengan melihat perkembangan laporan keuangan yang dipublikasikan perusahaan setiap tahunnya. Kondisi makroekonomi merupakan faktor eksternal yang dapat mempengaruhi harga saham yaitu nflasi dan tingkat suku bunga BI serta faktor nternalnya yaitu CR, DER, EPS, dan ROE.

Pengukuran harga saham mengggunakan faktor fundamental emiten seperti CR, DER, EPS, ROE, nflasi, dan BI Rate akan dijelaskan secara rinci sebagai berikut:

Current Ratio (CR) adalah rasio likuiditas yang merupakan salah satu rasio yang paling umum digunakan untuk mengukur tingkat likuiditas atau kemampuan perusahaan dalam memenuhi kewajiban jangka pendek tanpa menimbulkan masalah (Kasmir, 2012). Besar kecilnya nilai CR akan mempengaruhi minat dan kepercayaan para nvestor terhadap perusahaan. Hal tersebut dikarenakan semakin besar nilai CR maka semakin tinggi kemampuan perusahaan untuk menutupi kewajiban jangka pendeknya, begitu pula sebaliknya (Arenggaraya \& Djuwarsa, 2020).

Debt to Equity Ratio (DER) adalah rasio leverage (penggunaan hutang) yang sering digunakan para analis dan para nvestor untuk melihat seberapa besar hutang perusahaan jika dibandingkan dengan ekuitas yang dimiliki oleh perusahaan atau para pemegang saham (Ardhefani dkk., 2021). Semakin tinggi nilai DER makan diasumsikan perusahaan memiliki resiko yang semakin tinggi terhadap likuiditas perusahaannya, hal tersebut menunjukkan tingginya ketergantungan permodalan perusahaan terhadap pihak luar sehingga beban perusahaan semakin berat. Para nvestor tentunya akan berkurang minat dan kepercayaannya terhadap suatu perusahaan karena tingkat pengembaliannya semakin kecil (I'niswatin dkk., 2020).

Earning Per Share (EPS) merupakan salah satu faktor yang digunakan dalam menganalisis market value suatu perusahaan (Kasmir, 2012). EPS memberikan informasi seberapa jauh kemampuan perusahaan menghasilkan laba untuk tiap lembar yang beredar kepada para pihak luar (ekstern) (Siddiq dkk., 2020). EPS akan sangat berguna apabila dibandingkan dengan EPS pada perusahaan sejenisnya. Earning Per Share akan memberikan suatu gambaran yang sangat jelas tentang kekuatan profitabilitas antara perusahaan yang bersangkutan dengan perusahaan pembandingnya. Perlu diketahui bahwa perusahaan pembandingnya harus merupakan perusahaan yang bergerak di jenis ndustri yang sama. Earning per Share atau EPS ni apabila dihitung selama beberapa tahun, maka akan menunjukan apakah profitabilitas perusahaan tersebut semakin membaik atau malah semakin memburuk. Semakin tinggi nilai EPS maka akan semakin besar pula laba yang disediakan untuk pemegang saham, sedangkan rendahnya nilai EPS maka akan semakin kecil pula laba yang disediakan untuk pemegang saham.

Return On Equity (ROE) adalah rasio profitabilitas yang merupakan kemampuan suatu perusahaan dalam mengelola iekuitas (modal sendiri) untuk menghasilkan laba bagi nvestor (Kasmir, 2012). Para nvestor dapat melihat keuntungan yang benar-benar akan diterima dalam bentuk dividen. ROE yang tinggi menunjukkan perusahaan dapat memberikan keuntungan bagi pemegang saham, sedangkan ROE yang rendah menunjukkan perusahaan kurang mampu dalam memberikan keuntungan.

Inflasi imerupakan suatu keadaan dimana harga-harga dari barang dan jasa mengalami kenaikan yang berlangsung pada waktu yang cukup lama dan terjadi secara merata (Tandelilin, 2001). nflasi adalah proses dari suatu peristiwa, bukan tinggi-rendahnya tingkat harga. Dengan demikian, tingkat harga yang dianggap tinggi belum tentu menunjukan nflasi. nflasi dapat menjadi ndikator untuk melihat tingkat perubahan serta dianggap terjadi jika proses kenaikan harga berlangsung secara terus-menerus dan saling pengaruh memengaruhi. stilah nflasi juga digunakan untuk mengartikan peningkatan persediaan uang yang kadangkala dilihat sebagai penyebab meningkatnya harga (Tripuspitorini \& Setiawan, 2020). nflasi mencerminkan stabilitas ekonomi, secara teori nflasi bisa melemahkan semangat masyarakat untuk menabung (Marginal 
Propensity to Save turun), kecenderungan berbelanja meningkat (Marginal Propensity to Consume naik) dan akan mengarah terhadap nvestasi non-produktrif (Anisa \& Fifi, 2019). Semakin besar tingkat nflasi maka akan menjadi sebuah sentiment negatif bagi para pemegang saham, sehingga dapat menyebabkan harga saham suatu perusahaan menurun.

BI Rateididefinisikan sebagai suku bunga kebijakan yang mencerminkan sikap atau stance kebijakan moneter yang ditetapkan oleh bank ndonesia dan diumumkan kepada publik (www.bi.go.id). Bank ndonesia pada umumnya akan menaikkan BI rate apabila nflasi ke depan diperkirakan melampaui sasaran yang telah ditetapkan, sebaliknya Bank ndonesia akan menurunkan BI rate apabila nflasi ke depan diperkirakan berada di bawah sasaran yang telah ditetapkan. Kenaikan nflasi disebabkan karena jumlah uang yang beredar terlalu banyak. Hal tersebut membuat Bank ndonesia menaikkan tingkat BI rate.

BI Rate merupakan isalah satu faktor penting yang dapat mempengaruhi perubahan harga saham di pasar modal di ndonesia. Kenaikan BI rate mendorong masyarakat untuk menabung sehingga jumlah uang yang beredar berkurang. Sukirno (2013) menyatakan "Suku bunga adalah persentasi pendapatan yang diterima oleh para penabung dari tabungan uang yang disisihkannya". Sementara Bodie (2014) menjelaskan bahwa "Suku bunga yang tinggi mengurangi nilai kini dari arus kas mendatang, sehingga daya tarik peluang nvestasi menjadi turun". Hal tersebut dapat menyebabkan berkurangnya minat para nvestor untuk menanamkan modal di suatu perusahaan dan akan mempengaruhi harga saham suatu perusahaan tu sendiri.

Berdasarkan teori yang telah dijelaskan diatas, maka kerangka berpikir dalam penelitian ni dapat dilihat pada gambar 1 .

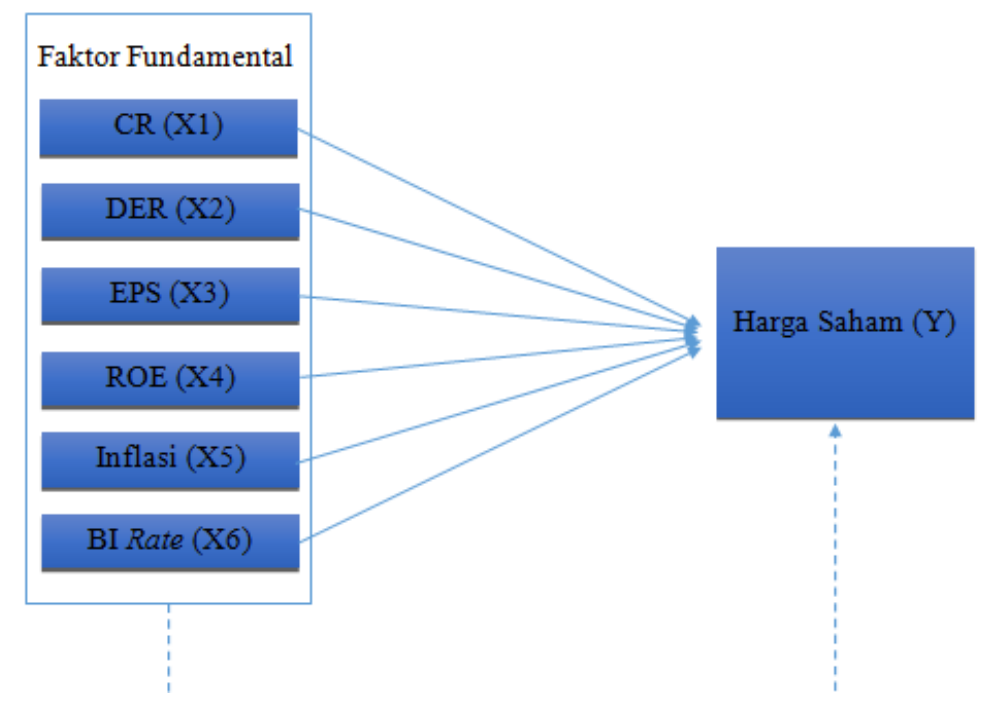

Gambar 1. Kerangka Penelitian

\section{Metode Penelitian}

Jenis ipenelitian yang digunakan dalam penelitian ni merupakan penelitian deskriptif. Penelitian deskriptif merupakan sebuah penelitian yang bertujuan untuk memberikan atau menjabarkan suatu keadaan atau fenomena yang terjadi saat ni dengan menggunakan prosedur lmiah untuk menjawab masalah secara aktual (Sugiyono, 2011). Penelitian ni memiliki dua variabel yakni variabel dependen dan ndependen. Variabel dependen adalah variabel yang dipengaruhi oleh variabel lain. Sedangkan variable ndependen adalah variabel yang mempengaruhi variabel lain. Variabel bebas (independent variable) meliputi CR(X1), DER(X2), 
EPS(X3), ROE(X4), nflasi(X5), dan BI Rate(X6). Variabel terikat dalam penelitian ni adalah Harga Saham (Y).

Populasi penelitian ni adalah perusahaan yang terdaftar (listing) di ndeks saham syariah yakni Jakarta slamic ndex. Sampel yang digunakan dalam penelitian ni diambil dengan metode purposive sampling yaitu teknik penentuan sampel dengan berbagai pertimbangan tertentu. Sampel pada penelitian ni adalah perusahaan yang konsisten terdaftar di Jakarta slamic ndex selama periode 2014-2018 atau selama 5 tahun berturut-turut dan tidak melakukan kebijakan Stock Split.

Data yang digunakan dalam penelitian ni merupakan data kuantitatif yang menurut sumbernya merupakan data sekunder. Data kuantitatif adalah data yang berbentuk kumpulan angka-angka, sedangkan data sekunder merupakan data yang diperoleh secara tidak langsung. Data sekunder dalam penelitian ni menggunakan data runtut waktu (time series) dan data antar ruang (cross section). Penggabungan kedua data tersebut biasa disebut juga dengan data panel.

Penelitian ni memiliki enam variabel bebas dan satu varabel terikat. Sehingga dengan hal ni regresi linear berganda dinyatakan dalam persamaan matematis sebagai berikut:

$$
\mathbf{Y}=\alpha+\mathbf{b}_{1} \mathbf{X}_{1}+\mathbf{b}_{2} \mathbf{X}_{2}+\mathbf{b}_{3} \mathbf{X}_{3}+\mathbf{b}_{4} \mathbf{X}_{4}+\mathbf{b}_{5} \mathbf{X}_{5}+\mathbf{b}_{6} \mathbf{X}_{6}
$$

Pengujian secara simultan, Uji statistik F digunakan untuk menguji kepastian pengaruhdari seluruh variabel ndependen secara bersama-sama Kriteria pengujian hipotesis untuk uji statistik F Bila Fsignifikan $<0,05$ maka secara simultan berpengaruh. Bila Fsignifikan $>0,05$ maka secara simultan tidak berpengaruh.

Pengujian secara parsial (Uji Statistik T). Uji statistik T digunakan untuk menguji pengaruh secara parsial antara variabel ndependen dengan asumsi bahwa variabel lain dianggap konstan. Kriteria pengujian uji $\mathrm{t}$ adalah Bila tsignifikan $<0,05$ maka secara parsial berpengaruh namun bila tsignifikan $>0,05$ maka secara parsial tidak berpengaruh.

\section{Hasil dan Pembahasan}

Isi memuat diskusi mengenai gagasan atau masalah pokok yang dibahas secara sistematis. (Garamound, size 12, Spacing: before 4 pt; after 4 pt, Line spacing: 1)

Dari 12 perusahaan yang telah memenuhi kriteria sampling, didapatkan hasil regresi linier berganda menggunakan Eviews 9 yakni sebagai berikut :

\section{Prcit $=4.014635-0.226935 \mathrm{CRit}-0.127464 \mathrm{DERit}-0.123843 \mathrm{EPSit}+$ 0.553295ROEit - 0.076332INFit - 0.202575TSBit}

Ket.

Prcit $=$ Price (Harga Saham)

CRit $=$ Current Ratio

DERit $=$ Debt to Equity Ratio

EPSit $=$ Earning Per Share

ROEit $=$ Return On Equity

$\mathrm{INFit}=$ nflasi

TSBit $=$ Tingkat Suku Bunga

Uji normalitas digunakan untuk menguji nilai residual yang dihasilkan oleh regresi 
berdistribusi normal atau tidak. Nilai probabilitas Jarque Bera lebih besar dari taraf signifikansi $(0.818239>0.05)$, artinya $\mathrm{H} 0$ diterima dan residual mempunyai distribusi normal.

Uji Multikolinearitas digunakan untuk menilai adakah korelasi atau nterkolerasi antar variabel bebas dalam model regresi, dalam hal ni, CR, DER, EPS, ROE, nflasi, dan tingkat suku bunga. Nilai korelasi dari masing-masing variabel bebas $<0.85$ artinya H0 diterima atau tidak terjadi masalah multikolinearitas.

Uji Autokorelasi digunakan untuk mengetahui penyimpangan asumsi, yaitu adanya korelasi yang disebabkan oleh residual pada satu pengamatan dengan pengamatan lain di dalam model regresi. Nilai probabilitas chi-square sebesar 0.0801. Nilai probabilitas chi-square lebih besar dari taraf signifikansi $(0.0801>0.05)$, artinya H0 diterima atau tidak terdapat autokorelasi.

Uji Heteroskedastisitas digunakan untuk melihat apakah terdapat penyimpangan asumsi pada model regresi. Penyimpangan ni disebabkan oleh adanya ketidaksamaan varians dari residual untuk semua pengamatan dalam model regresi. Nilai probabilitas chi-square sebesar 0.5864. Nilai probabilitas chi-square lebih besar dari taraf signifikansi $(0.5864>0.05)$, artinya H0 diterima atau tidak terdapat heteroskedastisitas.

Output uji $\mathrm{F}$ dalam penelitian kali ni menunjukkan nilai $\mathrm{F}$-statistik $>\mathrm{F}$ tabel yaitu $104.9024>2.36$ dan menunjukkan nilai probabilitas $0.000<0.05$, sehingga dapat disimpulkan bahwa secara simultan variabel CR,DER,EPS,ROE, nflasi, dan BI Rate berpengaruh secara signifikan terhadap harga saham perusahaan yang konsisten terdaftar di Jakarta slamic ndex periode 2014-2018. Sedangkan jika kita melihat hasil uji parsial (uji t).

Hasil penelitian menunjukkan bahwa Current Ratio (CR) berpengaruh negatif dan tidak signifikan terhadap harga saham perusahaan yang konsisten terdaftar di Jakarta Islamic Index periode 2014-2018. Hal ini dibuktikan dengan hasil uji t menyimpulkan nilai t hitung sebesar 1.342811 dengan nilai probabilitas 0.1854 lebih besar dari p-value $0.05(\alpha=5 \%)$. Maka CR tidak berpengaruh signifikan terhadap harga saham JII.

Hasil penelitian menunjukkan bahwa Debt to Equity Ratio (DER) berpengaruh negatif dan tidak signifikan terhadap harga saham perusahaan yang konsisten terdaftar di Jakarta Islamic Index periode 2014-2018. Hal ini dibuktikan dengan hasil uji t menyimpulkan nilai t hitung sebesar -0.748744 dengan nilai probabilitas 0.4575 lebih besar dari $p$-value $0.05(\alpha=5 \%)$. Maka DER tidak berpengaruh signifikan terhadap harga saham JII.

Hasil penelitian menunjukkan bahwa Earning Per Share (EPS) berpengaruh negatif dan tidak signifikan terhadap harga saham perusahaan yang konsisten terdaftar di Jakarta Islamic Index periode 2014-2018. Hal ini dibuktikan dengan hasil uji t menyimpulkan nilai t hitung sebesar -0.770171 dengan nilai probabilitas 0.4448 lebih besar dari $p$-value $0.05(\alpha=5 \%)$. Maka EPS tidak berpengaruh signifikan terhadap harga saham JII.

Hasil penelitian menunjukkan bahwa Return On Equity (ROE) berpengaruh positif dan signifikan terhadap harga saham perusahaan yang konsisten terdaftar di Jakarta Islamic Index periode 2014-2018. Hal ini dibuktikan dengan hasil uji t menyimpulkan nilai t hitung sebesar 3.485858 dengan nilai probabilitas 0.0010 lebih kecil dari $p$-value $0.05(\alpha=5 \%)$. Maka ROE berpengaruh signifikan terhadap harga saham JII.

Hasil penelitian menunjukkan bahwa Inflasi (INF) berpengaruh negatif dan tidak signifikan terhadap harga saham perusahaan yang konsisten terdaftar di Jakarta Islamic Index periode 2014-2018. Hal ini dibuktikan dengan hasil uji t menyimpulkan nilai t hitung sebesar 0.891564 dengan nilai probabilitas 0.3769 lebih besar dari p-value $0.05(\alpha=5 \%)$. Maka Inflasi tidak berpengaruh signifikan terhadap harga saham JII.

Hasil penelitian menunjukkan bahwa Tingkat Suku Bunga (TSB) berpengaruh negatif dan tidak signifikan terhadap harga saham perusahaan yang konsisten terdaftar di Jakarta Islamic Index periode 2014-2018. Hal ini dibuktikan dengan hasil uji t menyimpulkan nilai t hitung sebesar -1.605675 dengan nilai probabilitas 0.1146 lebih besar dari $p$-value $0.05(\alpha=5 \%)$. Maka 
tingkat suku bunga (BI Rate) tidak berpengaruh signifikan terhadap harga saham JII.

\section{Penutup}

Secara simultan variabel CR, DER, EPS, ROE, nflasi, dan BI rate berpengaruh signifikan terhadap harga saham perusahaan yang konsisten terdaftar di Jakarta slamic ndex periode 20142018.

Secara parsial variabel ROE berpengaruh signifikan terhadap harga saham Jakarta slamic ndex, sedangkan CR, DER, EPS, nflasi, dan BI Rate berpengaruh negatif dan tidak signifikan terhadap harga saham perusahaan yang konsisten terdaftar di Jakarta slamic ndex periode 20142018.

Dengan keterbatasan dalam penelitian ni, diharapkan penelitian selanjutnya agar dapat menambah jumlah sampel yang digunakan dalam penelitian agar hasil yang diperoleh akan semakin akurat. Kemudian diharapkan pula mampu mencakup dua faktor penentu kinerja perusahaan, yakni faktor finansial dan juga faktor analitikal perusahaan supaya output yang dihasilkan semakin akurat.

\section{Daftar Pustaka}

Anisa, L. S., \& Tripuspitorini, F. A. (2019). Analisis Pengaruh Dana Pihak Ketiga, Non Performing Finance Murabahah, Dan Inflasi Terhadap Pembiayaan Murabahah Pada Bank Umum Syariah Di Indonesia. Jurnal Maps (Manajemen Perbankan Syariab), 3(1), 52-64.

Aprilia, A. D., Nurdin, A. A., \& Mai, M. U. (2021). Analisis Pembentukan Portofolio Optimal dan Penentuan Nilai Risiko pada Saham Syariah. Journal of Applied Islamic Economics and Finance, 1(2), 487-498.

Ardhefani, H., Pakpahan, R., \& Djuwarsa, T. (2021). Pengaruh CR dan DER terhadap ROA pada Perusahaan Kosmetik dan Barang Keperluan Rumah Tangga. Indonesian Journal of Economics and Management, 1(2), 341-351.

Arenggaraya, K., \& Djuwarsa, T. (2020). Pengaruh Faktor Internal dan Faktor Eksternal Terhadap Harga Saham Perusahaan Sektor Pertambangan di ISSI. Journal of Applied Islamic Economics and Finance, 1(1), 200-213.

Awala, L., Djuwarsa, T., \& Danisworo, D. S. (2020). Perbandingan Return dan Risiko Saham Subsektor Perbankan dengan Subsektor Property Real Estate yang Terdaftar di BEI. Indonesian Journal of Economics and Management, 1(1), 111-123.

Bodie, Kane, \& Marcus. 2014. Investment. Tenth Edition. New York: McGraw-Hill Education.

I'niswatin, A., Purbayati, R., \& Setiawan, S. (2020). Pengaruh Debt to Equity Ratio dan Return on Equity terhadap Harga Saham pada Perusahaan Makanan dan Minuman yang Terdaftar di Bursa Efek Indonesia. Indonesian Journal of Economics and Management, 1(1), 96-110.

Kasmir. 2012. Analisis Laporan Kenangan. Jakarta: PT. Raja Grafindo Persada

Setiawan, S., Wulansari, P., \& Dewi, R. P. K. (2020). Pengukuran Tingkat Kinerja Keuangan Dan Kinerja Non Keuangan Pada Bank Syariah Di Lima Negara Asia (Studi Kasus pada Bank Syariah dengan Aset Tertinggi). Dinamika Akuntansi Keuangan Dan Perbankan, 9(1), 6978.

Siddiq, R. M., Setiawan, S., \& Nurdin, A. A. (2020). Pengaruh Likuiditas, Solvabilitas, dan Profitabilitas terhadap Earning per Share pada Bank Umum yang Terdaftar di Bursa Efek Indonesia. Indonesian Journal of Economics and Management, 1(1), 72-82.

Sudiyatno, Bambang. 2010. Peran Kinerja Kenangan dalam menentukan Faktor Fundamental 
Makroekonomi, Risiko Sistematis, Kebijakan Perusahaan terhadap nilai perusahaan. Disertasi Dokter Ilmu Ekonomi Universitas Diponegoro Semarang.

Sugiyono. 2011. Metode Penelitian Pendidikan (Pendekatan Kuantitatif, Kualitatif, dan R $\mho D$ ). Bandung: Alfabeta

Sukirno, Sadono. 2013. Makro Ekonomi, Teori Pengantar. Jakarta: PT. Raja Grafindo Persada.

Tripuspitorini, F. A., \& Setiawan, S. (2020). Pengaruh Faktor Makroekonomi Terhadap Pertumbuhan Dana Pihak Ketiga Pada Bank Umum Syariah di Indonesia. Jurnal Riset Akuntansi Dan Keuangan, 8(1), 121-132. https://doi.org/10.17509/jrak.v811.20228

Tandelilin, Eduardus. 2001. Analisis Investasi dan Manajemen Portofolio, Edisi Pertama. Yogyakarta: BPPE. 